\title{
Performance Analysis of Purse Seine with FADs and without FADs at Lappa Fishing Port, Sinjai
} Regency

\author{
Dewi Febriani Hamjan 1,*, Achmar Mallawa², Musbir ${ }^{3}$
}

\author{
${ }^{1}$ Student of Master Degree Fisheries Science, Faculty of Marine and Fisheries Science, Hasanuddin University, Perintis Kemerdekaan, \\ St.Km 10, Makassar 90245, Indonesia \\ ${ }^{2}$ Department of Fisheries Science, Faculty of Marine and Fisheries Science, Hasanuddin University, Perintis Kemerdekaan St Km 10 , \\ Makassar 90245, Indonesia \\ *Corresponding Author
}

\begin{abstract}
The purposed of this research is to analyze the performance of purse seine fishing gear operated on FADs and purse seines that hunt schools of fish (without FADs) based on four aspects of performance (biological, technical, social, economic). This research method is a survey method, taking 10 samples of each of the FAD purse seines and without FADs and analyzed using the scoring method through the biological, technical, socio-cultural and economic performance approaches. The results obtained by performed the FAD purse seine and non-FAD purse seine were in good enough criteria, namely $\geq 50-75 \%$. In general, the performance of the two fishing gear units did not have a significant difference, because there were similarities and differences that did not greatly differ from each aspect of the performance review. Based on the biological aspects, the performance of purse seine without FADs is better than that of the purse seine using FADs because catch fish with a suitable size and uniform species. whereas based on the economic and technical aspects, the performance of purse seine using FADs is better than purse seine without FADs. This is due to higher catch production and income. Based on the social aspect, the performance of both of them has no difference.
\end{abstract}

Keywords-Purse Seine, Biological Aspects, Technological Aspects, Economic Aspects, Social Aspects.

\section{INTRODUCTION}

Purse seine fishing gear in Sinjai Regency experiencing an average catch production increase $19.4 \%$ every year (DKP, 2013). Each purse seine fleet has a variety of factors that will affect the resulting production. This causes fishermen to continue to increase the use of fishing gear technology, one of which is the use of fishing aids, even though their use has had a negative impact on several aspects. The efficient use of technology in fishing operations is necessary so that fishermen can obtain maximum results and income. However, there are several problems faced by purse seine fishermen in maintaining fishing productivity and increasing the efficiency of using fisheries business production factors (Rajagukguk, 2018).

Another problem is that the fishing operation area is moving further away from the coast which increases fishing operational costs. Fishermen very depend on production factors in carrying out their activities. The income of fishermen is very much determined by the size of the production produced considering that the intensive provision for labor (ABK) is not based on the payroll system but with the profit sharing system that is applied. The use of fishing gear that does not pay attention to biological aspects plays a role in reducing catches, which reflects the problems faced by purse seine fishermen in maintaining catch productivity (Aprilla et al., 2013).

Fishing gear technology development, it is necessary to assess the fishing gear performance at the purse seine business unit using FADs or without FADs to know the catch and duration of catching both FAD and non-FAD purse seine, Knowing the production of the catch, the physical effects of the environment, fishing technology and the level of difficulty in operating both FAD and nonFAD trawl fishing gear, Knowing the business unit income and economic feasibility of both FAD and non-FAD purse seines and Knowing the level of technology acceptance, benefits, adaptability and legality of both FAD and non- 
FAD business units. So, this research can provide information about the performance of the purse seine fishing gear both using FADs and without FADs so it becomes a reference material for new fishery business actors or capital owners in developing the purse seine fishery business and becomes information and reference for the Fisheries Service in the management and utilization of fish resources and use of fishing gear.

\section{RESEARCH AND METHODS}

We conducted this research from May to December 2019 at the fishermen's base for catching purse seines who carried out operations in the waters of the Gulf of Bone. Purse seine fishermen comprise fishermen who use FADs as a tool and purse seine fishermen who hunt school of fish (without FADs). Sampling was also carried out at the Lappa Fish Landing Site, Sinjai Regency as the landing site for the fleet. The method used in this research is structured interviews based on four aspects (biological, technical, social and economic) and direct field observation to see the social conditions of the local community, the conditions of existing fishing gear, and the catch as primary data.

\subsection{Data Analysis}

The performance of the purse seine fishing gear using both FADs and without FADs was analyzed through biological, technical, socio-cultural and economic approaches. The fishing gear performance will be analyzed using the Scoring method used for the assessment criteria. For the lowest score is given 1 to the highest score is given

Table 1. The performance assessor of the ring tine using the scoring method

\begin{tabular}{|c|c|c|c|c|}
\hline Variable / sub variable & $\begin{array}{l}\text { The } \\
\text { value of } \\
\text { the sub } \\
\text { variable }\end{array}$ & Weight & $\begin{array}{l}\text { The value of } \\
\text { the variable } \\
\text { to }-i\end{array}$ & $\begin{array}{l}\text { Value } x \text { Weight } \\
\text { of the variable } \\
\text { to }-i\end{array}$ \\
\hline \multicolumn{5}{|l|}{ Biological Aspects } \\
\hline The size of the fish caught & & $\mathbf{0 , 5 0}$ & & \\
\hline 1. Small to large size is dominant & 1 & & & \\
\hline 2. Small to large size dominant medium size & 2 & & & \\
\hline 3 Small to large size dominant large size & 3 & & & \\
\hline 4. Medium to large sizes & 4 & & & \\
\hline Selectivity & & $\mathbf{0 , 5 0}$ & & \\
\hline 1.Catch $>5$ species, vary in size & 1 & & & \\
\hline 2. Catch $>5$ species, even size & 2 & & & \\
\hline 3. Catch $<5$ species, size varies & 3 & & & \\
\hline 4. Catch $>5$ species, even size & 4 & & & \\
\hline Catching Duration & & $\mathbf{0 , 5 0}$ & & \\
\hline 1. Catching > 10 months & 1 & & & \\
\hline 2. Catching $<6$ months & 2 & & & \\
\hline 3. Catching 8-10 months & 3 & & & \\
\hline 4. Catching 6-7 months & 4 & & & \\
\hline Length of peak fishing season & & $\mathbf{0 , 5 0}$ & & \\
\hline 1. Catching $>10$ months & 1 & & & \\
\hline 2. Catching <6 months & 2 & & & \\
\hline 3. Catching 8-10 months & 3 & & & \\
\hline 4. Catching 6-7 months & 4 & & & \\
\hline
\end{tabular}




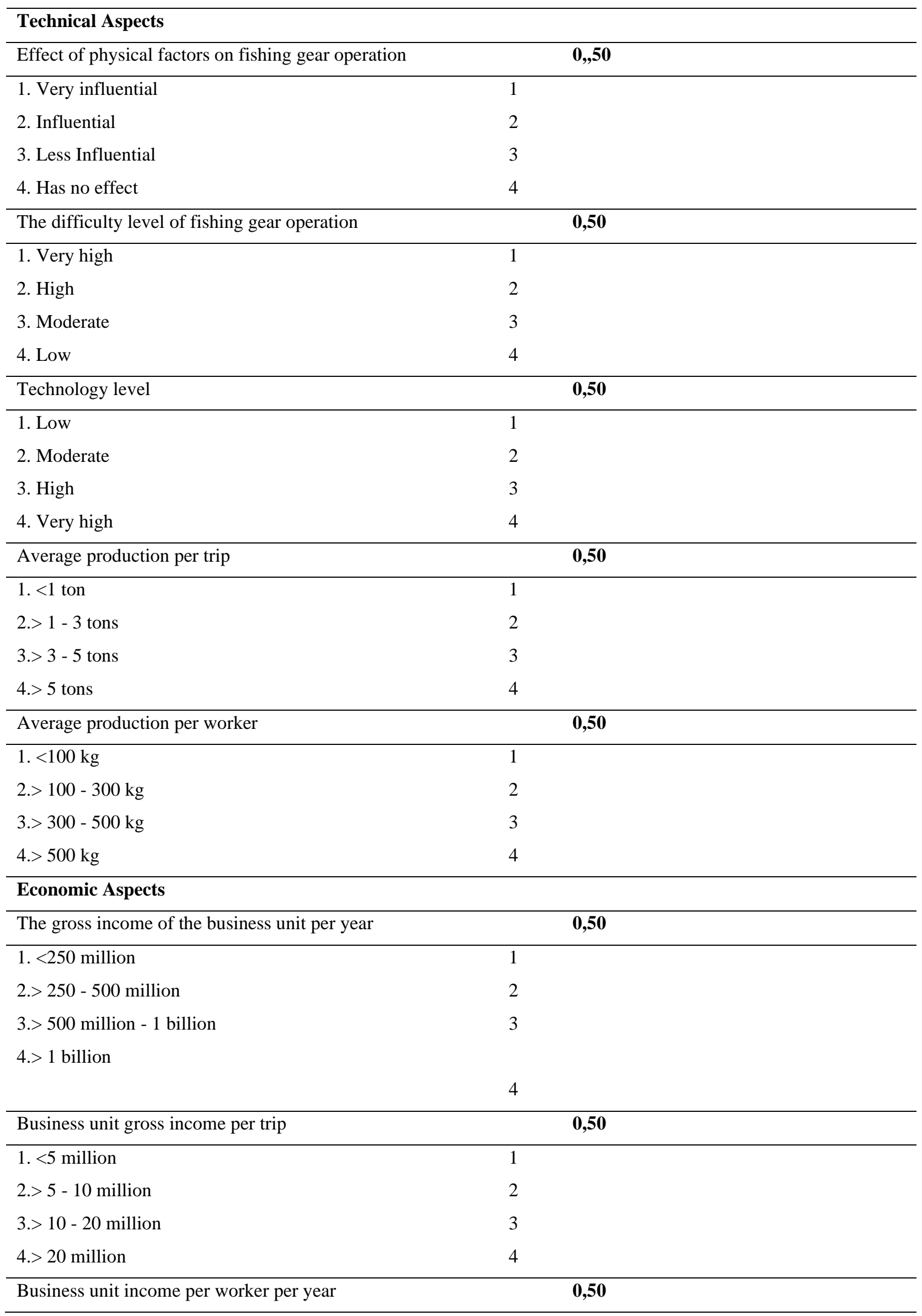




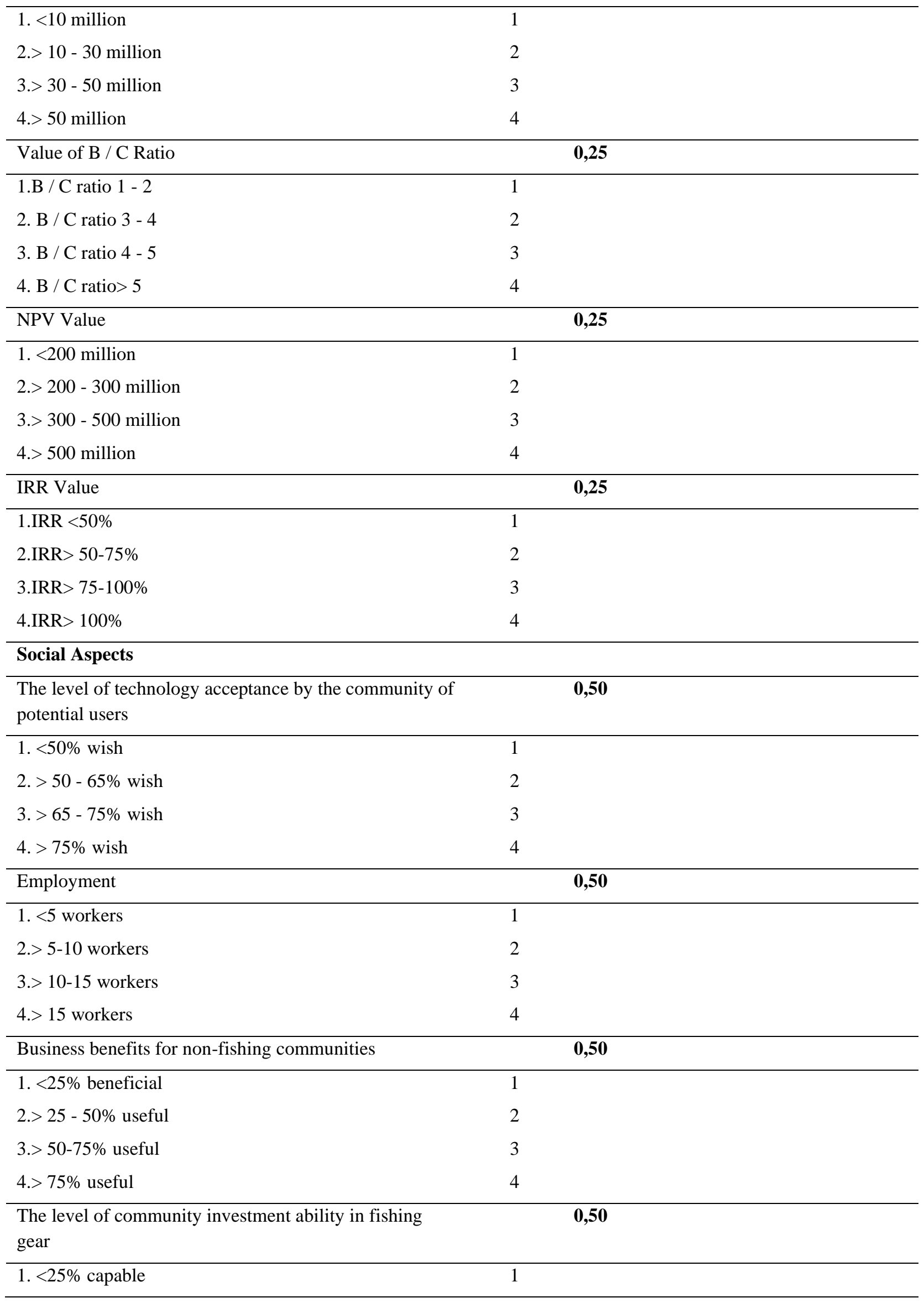




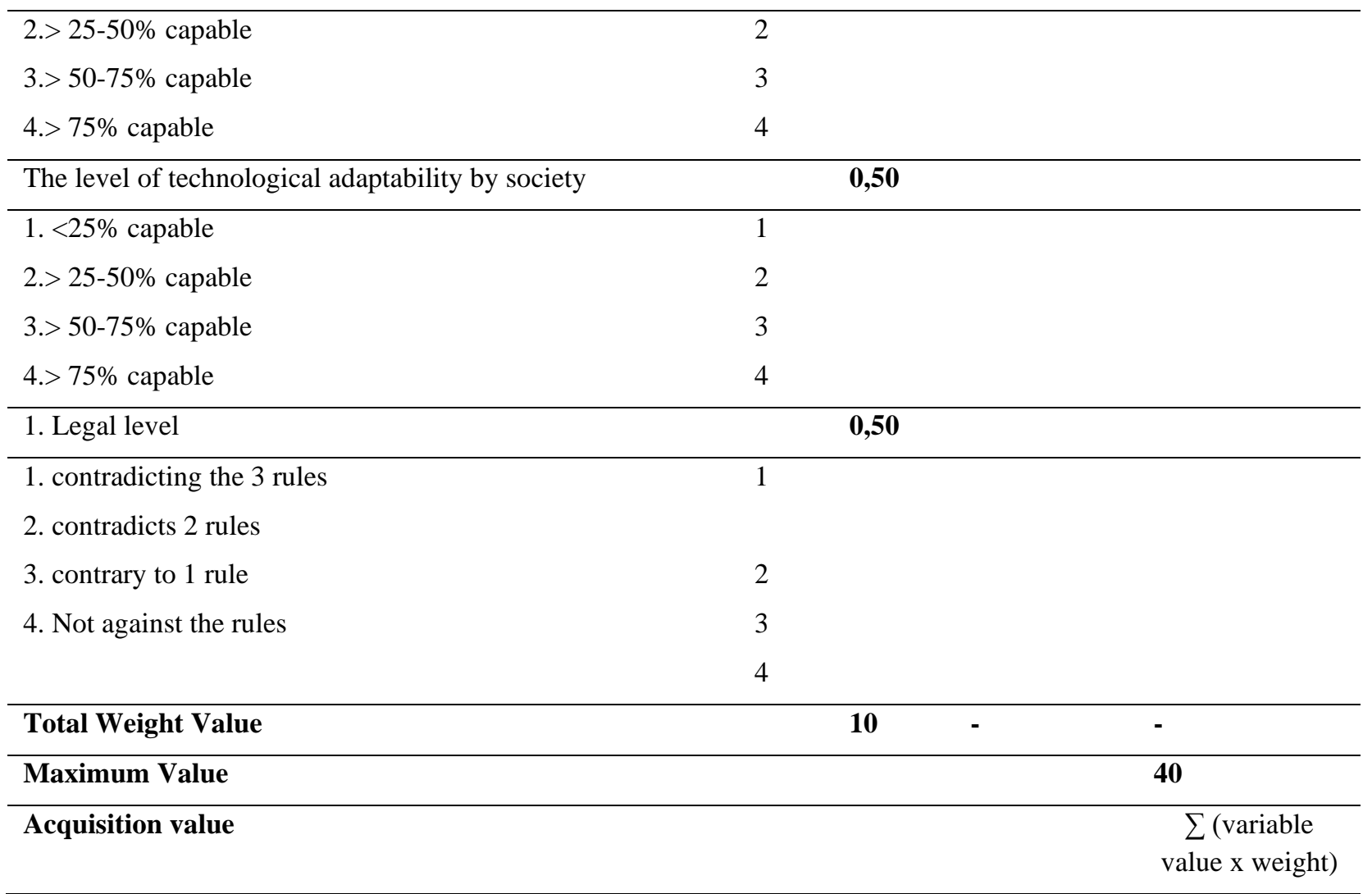

Source: Mallawa, 2019

Fishing Gear Performance $=(\mathrm{Vp} / \mathrm{Vm}) \times 100 \%$,

Where :

$\mathrm{V}_{\mathrm{p}}$ is the historical cost

$\mathrm{V}_{\mathrm{m}}$ is the maximum value or full value.

Performance Criteria:

If $\geq 85-100 \%$ very high or very good

$\geq 75-<85 \%$ High or Good

$\geq 50-75 \%$, high enough or good enough

$<50 \%$, Low or less good

\section{RESULT AND DISCUSSION}

3.1 Biological Aspects
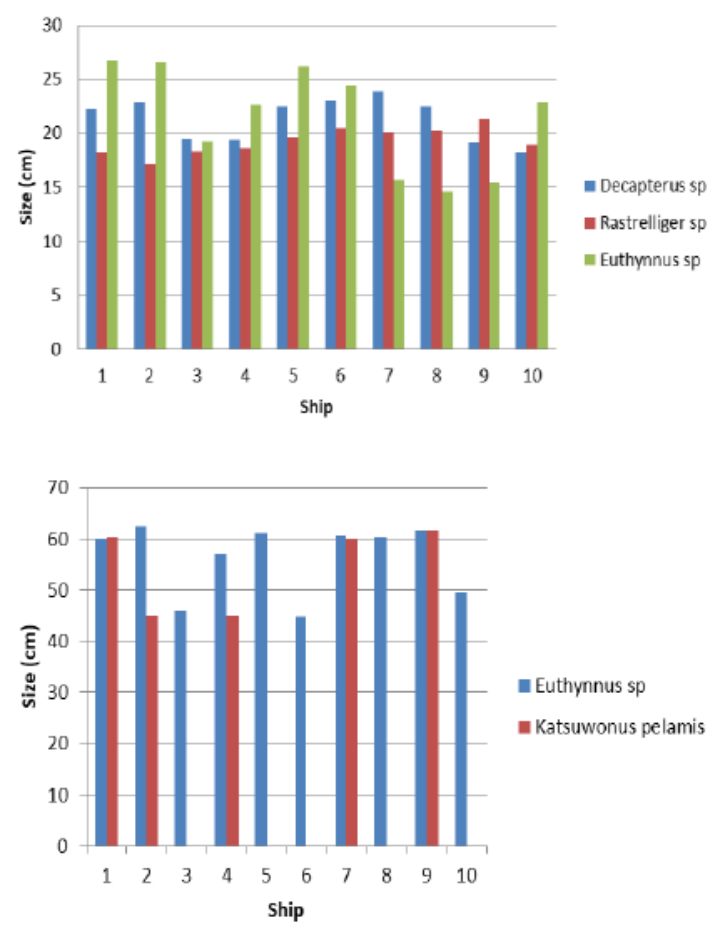

(B)

Fig.1 The size of the fish caught by purse seines: (A) using 


\section{FADs (B) without FADs}

Based on observations made at the Lappa Fishing Port Sinjai by measuring the length of the fish on each purse seine vessel using or without using FADs, it can be seen based on the picture above, namely the average catch size of the dominant fish species in the FAD purse seine ranges at $21.29 \mathrm{~cm}$ Decapterus $s p, 19.33 \mathrm{~cm}$ Rastrelliger $s p$ size and Euthynnus sp size $24.09 \mathrm{~cm}$ while in purse seine without FAD the average fish size is $56.36 \mathrm{~cm}$ and 54.40 $\mathrm{cm}$ for Euthynnus sp and Katsuwonus pelamis.

Observed from the selectivity of the fishing gear, the purse seine using FADs got catches of up to 5 types of fish with three types of dominant fish which vary in size from small to medium in each catch. The difference in catch size between purse seines using FADs and without FADs shows that there are also differences in fishing methods. Method of catching the FAD ring trawling is by taking a trip operating the fishing gear with the FADs assistive device and some using lights. Using FADs should lure several types of fish to gather in FADs to be caught so that fish species are not the target of being caught. In contrast to purse seines without FADs, operation is carried out by one day fishing and catches by chasing hordes of fish target catch without the aid of fishing tools so that the fish caught is the target fish species and minimize the types of fish that are not the target catch

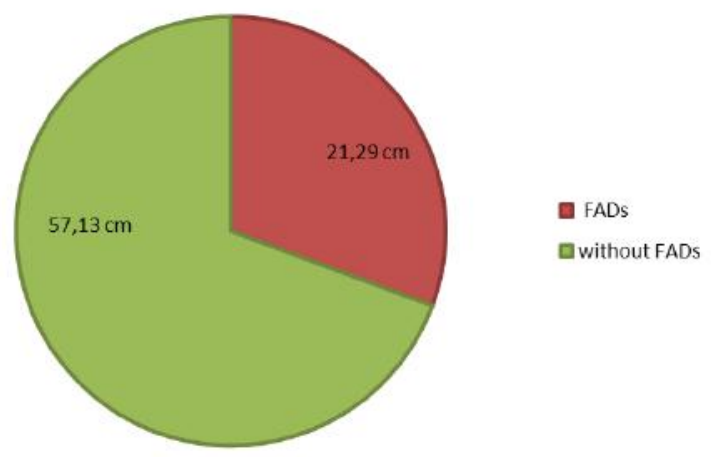

Fig. 2 Average Size of Mackerel Tuna (Euthynnus sp) on the

purse seine FADs and without FADs

Purse seines both using and without FADs have the same type of catch in the form of Euthynnus sp. The size obtained based on the observation is the average size of $21.29 \mathrm{~cm}$ in the purse seine business unit using FADs, while the average Euthynnus sp size of $57.13 \mathrm{~cm}$ is obtained by the purse seine business unit without using
FAD. The picture above shows that the size of the fish up to $57.13 \mathrm{~cm}$ is a medium size for Euthynnus $s p$ and 21.29 $\mathrm{cm}$ is a relatively small size. Wagiyo and Febrianti (2015) conducted research on the biological aspects of Euthynnus $s p$ and reported the size of the first time gonad ripe (Lm) was $40.34 \mathrm{~cm}$ and the size of the first time caught with purse seines (Lc) was $38.9 \mathrm{~cm}$ and was at the optimal exploitation level. This shows that the mackerel tuna in the purse seine FADs is not suitable to be caught, and the mackerel tuna as a non-FAD purse seine catch shows it is suitable to be caught.

The fishing period carried out by purse seine fishermen using or without FADs is all year round. The purse seines with FADs make fishing trips 2 times a month so that 24 fishing trips are obtained throughout the year. Purse seines without FADs are different because the catch is carried out one day fishing or the fishing operation is carried out one day to the fishing area and returns to the fishing base landing on the same day. The operating duration differs from purse seines using FADs are in operation for a maximum of up to 7 days.

\subsection{Technical Aspects}

The purse seine fishing gear is influenced by the physical factors of the waters, both purse seines using FADs and purse seines without FADs. The current becomes the thing that affects fishing gear operations. This will affect the performance of fishing gear and the ability of ships to determine fishing grounds. Likewise, the wind and waves can trigger the failure of fishing operations carried out by fishermen. According to Akhlak et al. (2015) Flow will affect the movement of fish and fishing gear. Determination of the location to be fishing is very important. Using purse seine fishing gear without FADs is to chase schools of fish as catch targets. Current direction, current speed, wave and wind. The direction and speed of the current affect when fishing is carried out because the target catch is determined by school of fish. The ship will move to change places to chase according to the whereabouts of the catch target. The fishing gear used by fishermen besides having technology capable of supporting the ability of the fishing gear in obtaining maximum fishing results must also be supported by the ability of fishermen to operate. Purse seine fishermen in Sinjai Regency do not experience difficulties in operating the non-FAD purse seine fishing gear. This greatly affects the effectiveness and efficiency of fishing operations. Although fishermen rely more on experience and abilities that are still traditional, the technology in fishing gear can help and make it easier for fishermen to increase their catch productivity. The picture below shows production of purse seine catch using FADs and without FADs. 

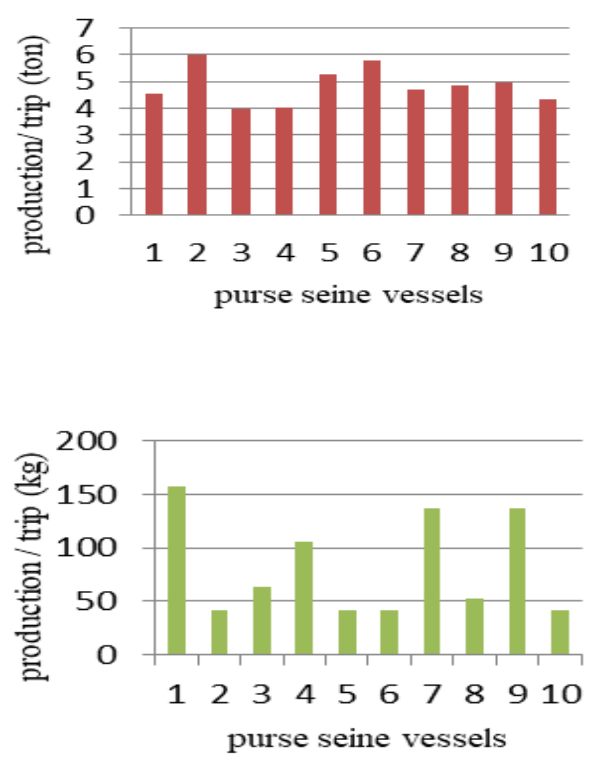

Fig 3. Production of purse seine catches: (A) FAD purse seines ( $B$ Non-FAD purse seines

Observations were made on purse seines using FADs or without FADs operating in Bone Bay and landing the caught fish at Pangkalan Pendaratan Ikan (PPI) Lappa. The average catch per trip was 4.8 tons or the equivalent of $4852 \mathrm{~kg}$ from 10 purse seines. Purse seines using FADs while purse seines without FADs get an average catch production of $81.9 \mathrm{~kg}$. The production of catches ranges from over 4 to 5 tons in purse seines using FADs while in the production of purse seines without FADs between 42 $\mathrm{kg}$ to $152 \mathrm{~kg}$ per fishing trip. This difference is because of the different operating times for each business unit. Catching purse seines using FADs lasts for 5 to 7 days on a single fishing trip and makes 2 trips in a month while purse seines without FADs carry out daily fishing operations or one day fishing can last up to 20 trips or more in a month. fishermen productivity is calculated based on the amount of production with the number of workers at a certain time. In the fisheries sub-sector, increasing productivity is directed at the use of production factors as efficiently as possible, including through education, both formal and non-formal education, and increasing fishermen's knowledge and skills. A significant difference is seen because the operating time of the two types of business units is different.

\subsection{Economic Aspects}

From an economic point of view, these two business units have considerable advantages. Purse seines using FADs as a fishing aid have greater economic advantages than purse seines without using FADs. The gross income per trip obtained by the purse seine business units using FADs is greater than the gross income per trip of the purse seines without using FADs. The difference is very significant. Purse seines without FADs income per trip is Rp. $1,950,000$ to Rp. $8,200,000$. Meanwhile, the purse seine business unit using FADs earns a gross income per trip is Rp. 55,600,000 to Rp. 77,300,000. This difference shows that the length of fishing operation carried out by these two business units affects the amount of revenue per trip. The purse seines business unit using FADs conducts fishing operations that last over 3 days, while the purse seine without FADs makes only one day catch. This shows that there is a difference in the catch's production per trip and is directly proportional to the income earned per fishing trip. The difference in income per trip for each business unit in purse seines without FADs shows that the purse seine business units without FADs get different production catches. The small income per trip shows that the production per trip is also small and vice versa, if the income per trip is high, the production of the catch is also high. This will then determine the amount of income earned by workers as in the image below.

Table 2. The gross income of the business unit per year

\begin{tabular}{llll}
\hline Name & $\begin{array}{l}\text { Purse seine } \\
\text { with FADs }\end{array}$ & Name & $\begin{array}{l}\text { Purse seine } \\
\text { Non-FADs }\end{array}$ \\
\hline Mekarsari & 1.632 .000 .000 & Putri T & 656.000 .000 \\
Bintang T & 1.856 .000 .000 & Asrianti & 234.000 .000 \\
Amira 01 & 1.524 .000 .000 & Hilda 01 & 628.000 .000 \\
Amira 02 & 1.524 .000 .000 & Hilda 02 & 522.000 .000 \\
Heriani & 1.784 .000 .000 & Hilda 03 & 522.000 .000 \\
Arjuna & 1.480 .000 .000 & PTK & 627.200 .000 \\
Minasa M & 1.544 .000 .000 & Aldi S & 963.200 .000 \\
Samudra & 1.516 .000 .000 & Askin & 708.000 .000 \\
Lisna Indah & 1.480 .000 .000 & Cahaya 01 & 723.600 .000 \\
Badar & 1.336 .000 .000 & Cahaya 02 & 698.400 .000 \\
\hline
\end{tabular}

Source: Primary Data, 2020 
International Journal of Environment, Agriculture and Biotechnology, 5(5)

Sep-Oct, 2020 / Available: https://ijeab.com/

Table 3. The gross income of the business unit per trip

\begin{tabular}{llll}
\hline Name & $\begin{array}{l}\text { Purse seine } \\
\text { with FADs }\end{array}$ & Name & $\begin{array}{l}\text { Purse seine } \\
\text { Non-FADs }\end{array}$ \\
\hline Mekarsari & 65.000 .000 & Putri T & 8.200 .000 \\
Bintang T & 77.300 .000 & Asrianti & 1.950 .000 \\
Amira 01 & 63.500 .000 & Hilda 01 & 2.600 .000 \\
Amira 02 & 63.500 .000 & Hilda 02 & 4.300 .000 \\
Heriani & 77.300 .000 & Hilda 03 & 4.300 .000 \\
Arjuna & 61.660 .000 & PTK & 3.700 .000 \\
Minasa M & 67.300 .000 & Aldi S & 2.800 .000 \\
Samudra & 63.166 .000 & Askin & 2.950 .000 \\
Lisna Indah & 61.600 .000 & Cahaya 01 & 3.350 .000 \\
Badar & 55.600 .000 & Cahaya 02 & 3.200 .000 \\
\hline
\end{tabular}

Source: Primary Data, 2020

Table 4. Business unit income per worker per year

\begin{tabular}{llll}
\hline Name & $\begin{array}{l}\text { Purse seine } \\
\text { with FADs }\end{array}$ & Name & $\begin{array}{l}\text { Purse } \\
\text { seine Non- } \\
\text { FADs }\end{array}$ \\
\hline Mekarsari & 48.000 .000 & Putri T & 25.230 .769 \\
Bintang T & 54.588 .235 & Asrianti & 11.700 .000 \\
Amira 01 & 50.800 .000 & Hilda 01 & 31.400 .000 \\
Amira 02 & 50.800 .000 & Hilda 02 & 26.100 .000 \\
Heriani & 55.750 .000 & Hilda 03 & 21.750 .000 \\
Arjuna & 46.250 .000 & PTK & 26.133 .333 \\
Minasa M & 51.466 .000 & Aldi S & 37.046 .153 \\
Samudra & 58.307 .000 & Askin & 29.500 .000 \\
Lisna Indah & 49.333 .000 & Cahaya 01 & 27.830 .769 \\
Badar & 51.384 .615 & Cahaya 02 & 29.100 .000 \\
\hline Source: Primary Data, 2020 & & \\
\hline
\end{tabular}

Source: Primary Data, 2020

The average value (B / C) of the fishing effort ratio using purse seines without FADs is greater than 1, specifically 1.70, while purse seines using FADs have a value of 2.46 . This value shows that the fishing effort can be said to be workable to continue because the $\mathrm{B} / \mathrm{C}$ value is $>1$. The average NPV value in the fishing effort using purse seines without FADs is Rp.1,325,021,457 while purse seines use larger FADs worth Rp.5,798,980,944. The NPV value is positive, which is greater than 0 , this indicates that the fishing effort is feasible to continue. The average IRR value of the purse seine fishing effort without using FADs is $31.72 \%$ while the purse seine using FADs has a value of
$35.15 \%$. This value indicates that the IRR is greater than the interest rate of $12 \%$, so the fishing effort is feasible to continue.

\subsection{Social Aspects}

The labor required in the purse seine business unit without FADs, at least 10 people and can reach up to 13 people. This also means that people can get work every day in one fishing gear business unit. The purse seines using FADs can absorb a minimum workforce of 13 to 17 people in one fishing trip.

Using purse seine fishing gear in Sinjai District provides not only benefits to fishermen. However, the nonfishermen also feel the benefits. From the interviews conducted with the surrounding community, it was said that the existence of the purse seine fishing gear had a good impact on other businesses such as fuel, ice cubes, grocery shops, fish sellers and even snack sellers. Economic activities will go hand in hand with fishing activities. Observed from the technology adaptation by fishermen, the percentage of $70 \%$ assessed by the purse seine technology using FADs is lower than the purse seine technology without FADs, which is $80 \%$ able to adapt to fishing gear technology. The level of technology adaptability to society is considered capable of being in the middle of society. The fishing gear used by fishermen is fishing gear with adequate technology that supports the fishermen's ability to operate fishing gear. The community can adapt to the existence of this fishing gear, the use of technology accepted by the community, and does not harm it both economically and socially. From the legal point of view of the fishing gear, it is not against the existing regulations, except for administrative matters regarding the completeness of the business unit and fishing gear.

\subsection{Performance Analysis of Fishing Tools}

In general, if we see from the percentage value of the analysis results between the purse seines of FADs and non-FADs, there is no significant difference, both of them are at a fairly good level of performance. However, when viewed from the aspects that become the assessment study, both FAD and non-FAD purse seines have differences that affect the assessment in the analysis.If averaged, the percentage of performance value of purse seines without FADs is $62.24 \%$ and purse seines using FADs are $64.75 \%$. This shows that there is no significant difference between them. Purse seines using FADs had a greater value than purse seines without FADs although they only differed by $3 \%$. From the percentage of $62,245 \%: 64.75 \%$ meets the standard of performance criteria, which is over $50-75 \%$, then the business unit is in the medium or good enough criteria. This means that the business unit is under good 
criteria and is not included in the low performance criteria. The use of purse seine fishing gear business units, whether using FADs or not using FADs, means that it is still workable to continue as a business unit with considerations and efforts to improve performance.

Table 5. Performance Assessment of FAD Purse seines

\begin{tabular}{lccc}
\hline Name & $\begin{array}{l}\text { Acquisition } \\
\text { value }\end{array}$ & $\begin{array}{l}\text { Performance } \\
\text { Value }\end{array}$ & $\begin{array}{l}\text { Final score } \\
(\%)\end{array}$ \\
\hline Mekarsari & 25,5 & 0,6375 & 63,75 \\
Bintang T & 26,5 & 0,6625 & 66,25 \\
Amira 01 & 26 & 0,65 & 65 \\
Amira 02 & 26 & 0,65 & 65 \\
Heriani & 26,5 & 0,6625 & 66,25 \\
Arjuna & 26 & 0,65 & 65 \\
Minasa M & 26 & 0,65 & 65 \\
Samudra & 25,5 & 0,6375 & 63,75 \\
Lisna Indah & 25,5 & 0,6375 & 63.75 \\
Badar & 25,5 & 0,6375 & 63,75 \\
Performance & & & $63,75-66,25$ \\
Range & & & \\
Average & & & 64,75 \\
SD & & & 0,98 \\
\hline
\end{tabular}

Source: Primary Data, 2020

Table 6. Performance Assessment of Purse seines without FADs

\begin{tabular}{lccc}
\hline Name & $\begin{array}{l}\text { Acquisition } \\
\text { value }\end{array}$ & $\begin{array}{l}\text { Performance } \\
\text { Value }\end{array}$ & $\begin{array}{l}\text { Final score } \\
(\%)\end{array}$ \\
\hline Putri T & 25,25 & 0,6312 & 63,12 \\
Asrianti & 24,75 & 0,6187 & 61,87 \\
Hilda 01 & 25,25 & 0,6312 & 63,12 \\
Hilda 02 & 24,75 & 0,6187 & 61,87 \\
Hilda 03 & 24,75 & 0,6187 & 61,87 \\
PTK & 24,25 & 0,6187 & 61,87 \\
Aldi S & 25,25 & 0,6312 & 63,12 \\
Askin & 24,75 & 0,6187 & 61,87 \\
Cahaya 01 & 24,75 & 0,6187 & 61,87 \\
Cahaya 02 & 24,75 & 0,6187 & 61,87 \\
Performance & & & $61,87-63,12$ \\
Range & & & 6,245 \\
Average & & & 0,60 \\
SD & & & \\
\hline Source: Pring & & & \\
\hline
\end{tabular}

Source: Primary Data, 2020

ISSN: 2456-1878

https://dx.doi.org/10.22161/ijeab.55.24

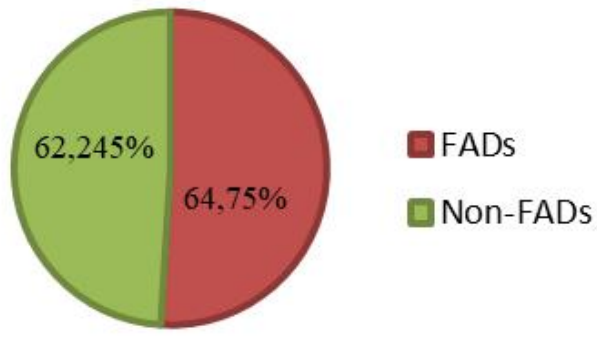

Fig 4. The average value of purse seine performance

\section{CONCLUSION}

The performance of FAD purse seines and non-FAD purse seines are in good criteria. Based on the biological aspects, the performance of purse seines without FADs is better than the purse seines using FADs, whereas based on the technical and economic aspects the performance of purse seines using FADs is better than the purse seines without FADs. Based on the social aspects of the performance of the two of them, there is no difference. The things that make both FAD and non-FAD purse seines do not have high performance, specifically the FAD purse seines involve the selectivity and size of the fish while in nonFAD purse seines include production and business unit income which is lower than that of the FAD purse seines. This research will provide information and reference for stakeholders to pay attention to the performance of fishing gear from the biological, technological, social and economic aspects by means of FAD purse seines to increase the productivity of the catch and nonFAD purse seines to pay attention to target fish caught.

\section{REFERENCES}

[1] Akhlak MA., Supriharyono., Hartoko, A. 2015. Relationship Of Variables, Sea Surface Temperature, Chlorophy And Results Of Purse Seine Capture Landed At Tpi Bajomulyo Juwana, Pati.

[2] Aprilla RM., Mustaruddin., Wiyono Es., Zulbainarni N. 2013. Efficiency Analysis Of Ring Trawl Catching Unit At Lampulo Beach Fishing Port, Banda Aceh. Journal Of Fisheries And Marine Technology. Vol. 4 No. 1.

[3] Department Of Marine Affairs And Fisheries Of Sinjai Regency. 2013. Marine And Fisheries Statistics Of Sinjai Regency. South Sulawesi. Indonesia.

[4] Mallawa, A. 2019. Performance Appraisal Analysis Using Scoring Method. Faculty Of Marine And Fisheries Sciences. Hasanuddin University. Makassar. 
[5] Rajagukguk, K. 2018. Productivity Of Purse Seine Capture Fisheries In Pekalongan Archipelago Fishery Port, Pekalongan City, Central Java Province. Faculty Of Fisheries, University Of Riau.

[6] Wagiyo K And Febrianti E. 2015. Biological Aspect And Population Parameters Of Longtail Tuna (Thunnus Tonggol) In Langsa And Adjacent Waters. Research Institute For Marine Fisheries, Jakarta. 